\title{
Interaction of Water Supply Planning and Environmental Protection
}

\author{
Daniel F. Luecke \\ Environmental Defense Fund, 1405 Arapahoe Avenue, Boulder, CO 80302
}

\section{PARADOX OF WATER-ITS REAL AND RHETORICAL VALUE}

Value of diverted water

A paradox arises in dealing with the value of water. Political and media rhetoric asserts that water is of enormous economic importance. This conventional view, however, contrasts with reality-water has a relatively low economic value at the margin, i.e., the point at which one additional unit of water would be used. Conceptually correct empirical estimates of the direct marginal value productivity (the value of the next unit used in production) of irrigation water usually range from $\$ 25$ to $\$ 75 /$ acre-foot $\left(\approx 1235 \mathrm{~m}^{3}\right)$ (Young, 1984). For most crops, estimates are in the lower part of this range, but some estimates even fail to reach the lower bound. Based on the cost of supply, the municipal water values are no more than an order of magnitude higher.

Variations within the range do exist. Irrigation water values can be as low as \$10/acre-foot in the Colorado River Basin, although it is probably higher in drainages such as the South Platte (Krutilla et al., 1983). In the lower Colorado River Basin, its value is about \$30/acrefoot (Howitt, 1980). Similar variations are found in other parts of the southwestern United States. For example, the value of irrigation water in the Texas rice-growing region is probably less than $\$ 40 /$ acre-foot (Ellis et al., 1984; Griffin et al., 1984).

In other words, resources devoted to water development, conservation, or management canjustify a cost of only 1.5 to 3 cents/ton (1.75.8 cents/t) for irrigation and perhaps 30 cents/ton (33 cents/t) for household use. While a substantial total economic value may still be implied for large water supply projects, the marginal value of irrigation water to the user is often insufficient to justify major capital expenditures.

\section{Value of undisturbed water}

Having looked at the value of water where it has a market price, what can be said about the intrinsic value of the natural system from which it is removed? Because aquatic ecosystems-habitats, wetlands, and streams--are not traded in conventional markets that reflect such values, other methods must be used to determine value. There are direct methods, such as contingent valuation (i.e., an individual's willingness to pay), and indirect methods that infer value from use. [For a thorough review of both, see Stavins (1984).] In addition, other survey methods try to estimate "option values" and "existence values" that are above and beyond what individuals would be willing to pay now to ensure access to, or existence of, an environmental resource in the future. Another approach bases a natural system's value on the cost of mitigating its loss should it be destroyed. Applying these methods appropriately can establish the value of natural systems and their associated water resources.

Some aquatic ecosystems are traded in the market. Some states have instream flow programs that allow water rights to be purchased to protect natural systems. Presumably, rights are purchased at market rates, and data on these purchases would indicate instream flow values. Moreover, ownership restrictions in some instream flow programs (e.g., Colorado's program prohibits privately owned instream rights) may reflect a concern that instream flow values would set the price (were a market to operate freely). Closing such interests out of the market suggests there may be fear, in some quarters at least, that instream values may exceed those of traditional "beneficial use" categories.

Natural systems do have value-a measurable (if only indirectly in certain cases) and significant value, with regard to the economic well- 
being of a region. Their loss cannot be left out of the accounting in water resource investment plans.

\section{Value of water-dependent natural systems if lost}

With regard to losing natural systems, a particularly interesting phenomenon arises when using direct methods to measure their value. Damage or loss in well-being can be measured by either the maximum sum individuals would be willing to pay to avoid the loss or by the minimum compensation they would require to accept it. The two methods were always assumed to yield equivalent results. However, recent evidence suggests a strong and consistent disparity between paying for avoiding loss vs. compensating for accepting it (Knetsch, 1984). In almost all cases, based on experimental and empirical data, the latter method yields values two to three times greater than the former, i.e., the compensation for accepting loss exceeds the willingness to pay to avoid it. Such a divergence becomes particularly important when assessing the economic attractiveness of a project that would destroy a natural system.

Despite the data, in discussing ways in which a region may use its water resources, there is a tendency to overemphasize water's value when it is diverted (see Colorado Assn. of Commerce and Industry, 1987) and underemphasize its value when it is undisturbed (Colorado Water Conservation Board, 1952). In the western United States, the conventional argument states that water must be developed to have worth, left in its natural course, it remains "unused" and, by implication, useless. It appears that the debate over water resources is based on 1) assuming a growth-inducing relationship that lacks an empirical foundation (see Falkenmark et al., 1987; Fullerton et al., 1975; Howe, 1968; Martin and Young, 1969), 2) an imputed value for water in certain applications that does not stand up to close examination, and 3) an accounting system that heavily discounts the worth of water in its natural state.

\section{STATUS OF WESTERN WATER ECONOMIES}

Western water economies have passed from their "expansionary" phase (i.e., new supplies were readily available; few interdependencies existed among users; and, after accounting for federal subsidies, projects were relatively inexpensive) into their "mature" phase (i.e., new supply costs are rapidly escalating; water users are linked by elaborate physical systems and are increasingly interdependent economically; and federal subsidies have evaporated) (Young, 1984). The systems have reached their present state under rules based primarily on technical feasibility, i.e., water management traditionally has been viewed as a technical or engineering problem. Thus, solving problems rather than efficiently allocating resources has been both the guiding principle and the basis for regarding achievement (Young, 1986). Consequently, structural solutions favored by engineer-managers have led to elaborate physical systems. Believing in the hypothetical relationship between investments in water supply systems and economic development nurtured the process that led to selecting these solutions.
Given the maturity of water supply systems, the relative value of water in agricultural and municipal applications, and the increasing recognition of instream values, we are led to question the efficiency and equitability of methods used to allocate the resource and augment supplies. Applying a Pareto optimality criterion (i.e., a system's state is said to be Pareto optimal if one entity can become better off only at another's expense), decisions that involve supply expansion are wasteful and inefficient. However, using the same criterion, individual irrigators, residential water customers, and commercial and industrial users are likely to make appropriate water-use decisions. The apparent contradictions between system allocation decisions and individual user behavior are part of the paradox of overvaluing (but sometimes underpricing) water in certain applications while completely ignoring its value in others.

\section{Literature Cited}

Colorado Association of Commerce and Industry. 1987. Blueprint for Colorado: A plan for growth from the business community. Colorado Assn. Commerce and Industry, Denver.

Colorado Water Conservation Board. 1952. A hundred years of irrigation in Colorado. Colorado Agricultural and Mechanical College, Fort Collins.

Ellis, J.R., R.C. Griffin, and R.F. Ziemer. 1984. A supply-demand analysis of irrigation water use in the Texas rice belt. Dept. of Agronomy and Economics, Texas A\&M Univ., College Station.

Falkenmark, M., A.K. Biswas, H. Hori, T. Ishibashi, G. Kovacs, P. Rogers, and H.I. Shuval. 1987. Water-related limitations to local development. Ambio 16(4):191-200.

Fullerton, H.H., W.C. Lewis, J.C. Anderson, J.E. Keith, and R. Willis. 1975. Regional development: An econometric study of the role of water development in effectuating population and income changes. Utah Water Res. Lab., Utah State Univ., Logan.

Griffin, R.C., G.M. Perry, and G.N. McCauley. 1984. Water use and management in the Texas rice belt. Dept. of Agronomy and Economics, Texas A\&M Univ., College Station.

Howe, C.W. 1968. Water resources and regional economic growth in the United States, 1950-1960. Southern Econ. J. 34(4):477-489.

Howitt, R.E., W.D. Watson, and R.M. Adams. 1980. A reevaluation of price elasticities for irrigation water. Water Resources Res. 16(4):623-628.

Knetsch, J.L. 1984. Legal rules and the basis for evaluating economic losses. Intl. Rev. Law \& Econ. 4:507-521.

Krutilla, J.V., M.D. Bowes, and P. Sherman. 1983. Watershedmanagement for joint production of water and timber: A provisional assessment. Water Resources Bul. 19(3):403-414.

Martin, W.E. and R.A. Young. 1969. The need for additional water in the arid southwest: An economist's dissent. Ann. Regional Sci. 3(1):22-31.

Stavins, R. 1983. The Tuolumne River: Preservation of development? An economic assessment. Environmental Defense Fund, Berkeley, Calif.

Young, R.A. 1984. Local and regional economic impacts of competition for irrigation water, p. 244-272. In: E.A. Englebert and A.F. Scheming (eds.). Water scarcity: Impacts on western agriculture. Univ. of California Press, Berkeley.

Young, R.A. 1986. Why are there so few transactions among water users? Amer. J. Agr. Econ. 68(5):1143-1151. 